\title{
Assessment of radon content in water using SMART RnDuo in Mizoram, Northeast India
}

\author{
Hmingchungnunga ${ }^{1}$, Vanramlawma ${ }^{1}$, Remlalsiama $^{1}$, Laldingngheta $^{1}$, L.Z. Chhangte ${ }^{1}$, Z. \\ Pachuau $^{1}$, B. Zoliana ${ }^{2 *}$, Rosangliana ${ }^{2}$, B.K. Sahoo ${ }^{3}$, B.K Sapra ${ }^{3}$ \\ ${ }^{1}$ Department of Physics, Mizoram University, Tanhril 796004, Mizoram, India \\ ${ }^{2}$ Department of Physics, Government Zirtiri Residential Science College, Aizawl 796007, Mizoram, India \\ ${ }^{3}$ Radiological Physics and Advisory Division, Bhabha Atomic Research Centre, Mumbai 400085, India \\ *Corresponding author: bzoliana@gmail.com
}

\begin{abstract}
Radon is a radioactive inert gas that is produced naturally from the decay of uranium to radium. As it is formed, it is released into air or water-containing pores between soil and rock particles. From soil and rock natural forces move it into the earth and it dissolves in groundwater. This is of great medical concern as environmental radon is one of the major causes of dangerous health problems such as lung cancer. Measurements of radon content in water was carried out in the northeastern part of India namely Aizawl district and Kolasib district of Mizoram using SMART RnDuo. About 30 sources of water were examined in each district during the winter of 2017. Water samples were collected from stream water, spring water, pump water, open well, pond and Government supplied water. Radon content in water from Aizawl district ranges between $0.309 \mathrm{~Bq} / \mathrm{L}$ to $32.53 \mathrm{~Bq} / \mathrm{L}$, and those from Kolasib district the range is $1.11 \mathrm{~Bq} / \mathrm{L}$ to $22.18 \mathrm{~Bq} /$ $\mathrm{L}$. The overall average content of radon in water was found to be $6.88 \mathrm{~Bq} / \mathrm{L}$. The radon content measured for most of the sources were found to be well within the range which is considered safe (EPA 1998) except for few samples analysed.
\end{abstract}

Keywords: RnDuo, water source, radon content in water, Aizawl, Kolasib.

\section{INTRODUCTION}

Radon is naturally-occurring radioactive inert gas, with a half-life of 3.8 days produced from the decay of uranium to radium and then to radon. As radium decays, radon is formed and is released into air or watercontaining pores between soil and rock particles. If this occurs near the soil surface, the radon may be released to ambient air, at the same time it may also dissolve into groundwater (Prasad Ganesh et al., 2009). The presence of radon in water is predominantly due to the decay of radium found in rock and soil, and not from the radium dissolved in water (WHO, 2011). The principle characteristic of radon that gives it more radiological significance than earlier member of the uranium decay chain is the fact that it is a noble gas. Once it is formed, the transport and release from a soil into air or water occurs through diffusion and flow of the air or water (UNSCEAR, 1982).
Radon can therefore reach air or water to which humans have access, provided that transport took place before the radon decay (Nazaroff, 1988).

The major contribution of radiation dose in uranium decay series comes from radon (222Rn) which makes it one of the largest single sources of radiation exposure to the population (UNSCEAR, 2000). From the total radiation received by humans, radon and its decay products contributes $51 \%$ through inhalation and $0.21 \%$ through ingestion (Kumar et al., 2017). Measurement of radon concentration in water is also very significant for understanding radon migration processes (Singh et al., 2015). Therefore proper assessment of radon is required to assess the concentration of radon in water as it can associate with the public health.

In this paper, the radon content in water has been measured using SMART RnDuo detector from Kolasib and Aizawl districts within Mizoram during winter season from different sources, namely bore well, spring water, 
stream and government supplied water. The measurement is expected to provide a part of baseline data for radon content in water in Mizoram.

\section{Materials AND MethodS}

\section{Study area}

Figure 1 shows the geographical sites where the water samples were collected. The state of Mizoram is a hilly area with an average elevation of about 500 to 800 meters from sea level. It is a tropical region with moderate climate and the temperature varies from $11^{\circ} \mathrm{C}$ to $24^{\circ}$ $\mathrm{C}$ during the winter season and $18^{\circ} \mathrm{C}$ to $29^{\circ} \mathrm{C}$ during summer. The sampling area extends from $23^{\circ} 54^{\prime} 8.8^{\prime \prime}$ to $24^{\circ}$ $30^{\prime} 38.2^{\prime \prime}$ latitude and $92^{\circ} 35^{\prime} 54.4^{\prime \prime}$ to $92^{\circ} 51^{\prime} 38.1^{\prime \prime}$ longitude with an area of about $4957 \mathrm{sq} \mathrm{km}$. Water samples were collected from 64 different locations within the study area.

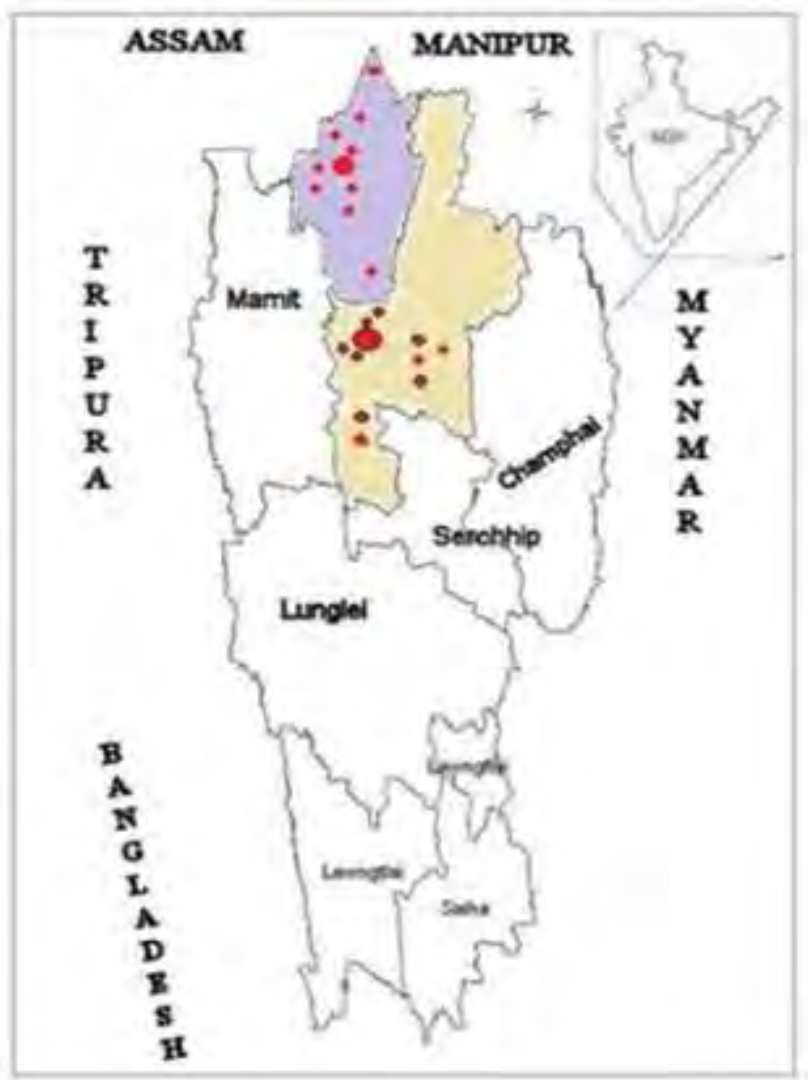

Figure 1: Map of Mizoram showing locations from where samples were collected.

\section{Radon measurement}

Radon content in water was obtained using SMART RnDuo which is a scintillation cell method. To measure radon content in water the radon gas in the setup was flushed for 5 minutes by using an inbuilt pump to eliminate any background. RnDuo monitor was connected with bubbler attached to the sampling bottle using flexible tubing as shown in Figure 2. Then the pump was on again for 3 minutes so that the dissolve radon can escape in to the tubing. Measurement was taken in 15 minutecycle for 1 hour. The radon concentration in liquid $\left(\mathrm{C}_{\text {liq }}\right)$ $(\mathrm{Bq} / \mathrm{m} 3)$ from the concentration measured in air $\left(\mathrm{C}_{\text {air }}\right)$ was calculated by using the equation:

$$
\mathrm{C}_{\mathrm{liq}}=C_{\text {air }}\left(K+\frac{v_{\text {air }}}{v_{\text {tiq }}}\right)
$$

Where $\mathrm{K}$ is partition coefficient of radon in liquid with respect to air, $V_{\text {air }}$ is volume of air and $V_{\text {liq }}$ is volume of liquid in sampling bottle.

\section{RESULTS}

Within this study area as shown in Figure 1, a total of 64 water sources were selected, 36 from Aizawl district and 28 from Kolasib district. Among these, water samples were taken from 36 samples are from springs, 19 samples from bore-well, 6 samples from streams and1 sample each from pond, open-well and Government supplied water. The radon content in water was found to be varying from $0.309 \mathrm{~Bq} / \mathrm{L}$ to $32.53 \mathrm{~Bq} / \mathrm{L}$ with an average of $6.88 \mathrm{~Bq} / \mathrm{L}$.

In Aizawl district, in the case of bore-well it was found to vary from $0.309-32.53 \mathrm{~Bq} / \mathrm{L}$ with an average of 11.14 $\mathrm{Bq} / \mathrm{L}, 1.04-20.74 \mathrm{~Bq} / \mathrm{L}$ in spring with an average of 5.28 $\mathrm{Bq} / \mathrm{L}, 1.22-6.56 \mathrm{~Bq} / \mathrm{Lin}$ streams with an average of 3.77 $\mathrm{Bq} / \mathrm{L}$. In Kolasib district, in the case of bore-well it was found to vary from 7.6-17.11 Bq/L with an average of 12.42 Bq/L, 1.11-22.17 Bq/Lin spring with an average of $5.26 \mathrm{~Bq} / \mathrm{L}$.

Figure 3 shows the comparison of average activity concentration of different water sources in Aizawl and Kolasib districts. In both cases, it can be seen that average activity concentration was found to be highest in bore-well. According to WHO, groundwater from wells and boreholes usually contains higher radon concentrations than surface waters (WHO, 2011) that is because ground water are enclosed and the radon content are not released in to the ambient air. The result obtained was in accordance with guidelines provided by WHO as mentioned above.

\section{DISCUSSION}

Radon is among environmental pollutants that can cause serious health effects. It is directly linked to the development of lung cancer, resulting in a number of deaths throughout the world (Yoon et al., 2018). It in- 


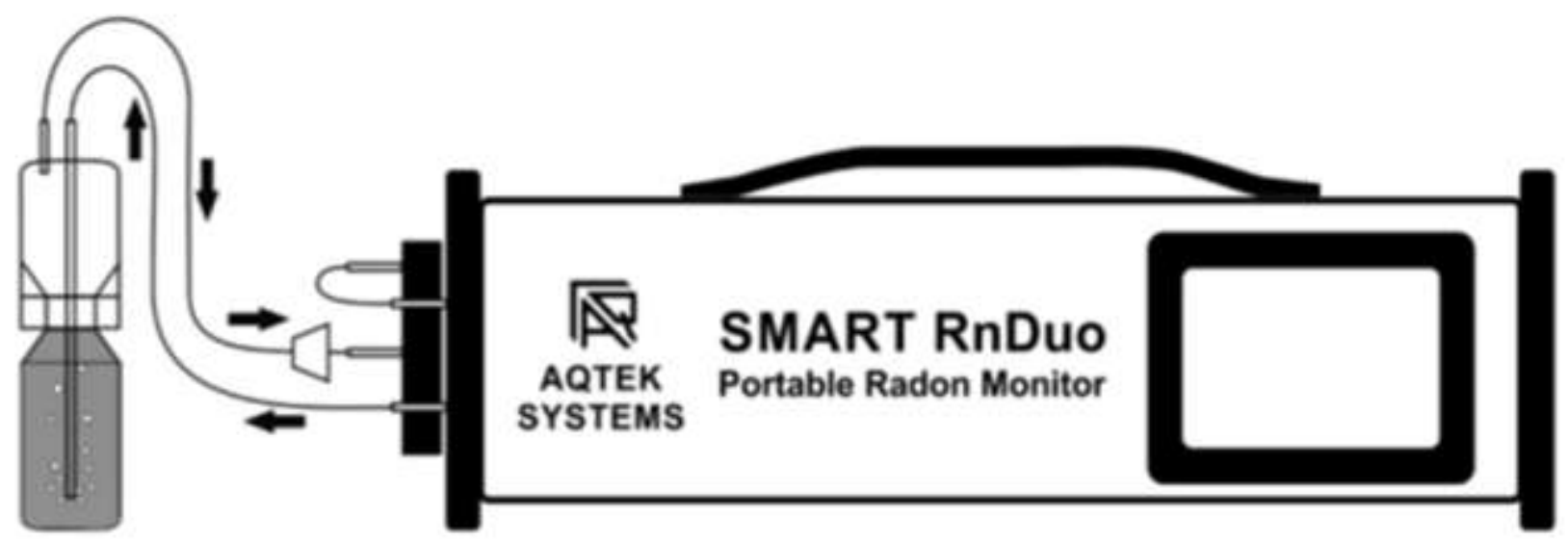

Figure 2: Schematic diagram of measurement of radon in water using RnDuo detector.

Table 1: Results of measurement of radon content in water using RnDuo in Aizawl and Kolasib district, Mizoram.

\begin{tabular}{|c|c|c|c|c|c|c|c|}
\hline $\begin{array}{l}\text { Sl. } \\
\text { No. }\end{array}$ & $\begin{array}{l}\text { Sample } \\
\text { Code }\end{array}$ & Sample source & $\begin{array}{c}\text { Radon in } \\
\text { water }(\mathrm{Bq} / \mathrm{L})\end{array}$ & Sl. No. & Sample Code & Sample source & $\begin{array}{c}\text { Radon in } \\
\text { water }(\mathrm{Bq} / \mathrm{L})\end{array}$ \\
\hline 1 & A-1 & Bore well & 3.904 & 33 & A-33 & Stream & 6.56 \\
\hline 2 & A-2 & Spring & 20.74 & 34 & A-34 & Spring & 4.89 \\
\hline 3 & A-3 & Bore Well & 9.028 & 35 & A-35 & Stream & 6.13 \\
\hline 4 & $A-4$ & Spring & 4.50 & 36 & A-36 & Supplied & 0.30 \\
\hline 5 & A-5 & Bore Well & 2.71 & 37 & $\mathrm{~K}-1$ & Borewell & 14.54 \\
\hline 6 & A-6 & Bore Well & 32.53 & 38 & $\mathrm{~K}-2$. & Spring & 1.26 \\
\hline 7 & A-7 & Spring & 9.41 & 39 & $\mathrm{~K}-3$. & Spring & 3.75 \\
\hline 8 & A-8 & Spring & 3.23 & 40 & K-4. & Spring & 5.57 \\
\hline 9 & A-9 & Bore Well & 21.85 & 41 & $\mathrm{~K}-5$. & Spring & 2.72 \\
\hline 10 & A-10 & Bore Well & 26.42 & 42 & K-6. & Spring & 2.29 \\
\hline 11 & A-11 & Spring & 6.97 & 43 & $\mathrm{~K}-7$. & Spring & 1.76 \\
\hline 12 & A-12 & Bore Well & 3.21 & 44 & K-8. & Borewell & 7.62 \\
\hline 13 & A-13 & Stream & 1.65 & 45 & K-9. & Spring & 10.11 \\
\hline 14 & A-14 & Bore Well & 15.53 & 46 & K-10. & Spring & 2.15 \\
\hline 15 & A-15 & Bore well & 5.34 & 47 & K-11. & Spring & 1.63 \\
\hline 16 & A-16 & Bore Well & 5.34 & 48 & K-12. & Spring & 2.37 \\
\hline 17 & A-17 & Spring & 2.37 & 49 & K-13. & Open-well & 8.49 \\
\hline 18 & A-18. & Bore Well & 1.48 & 50 & K-14. & Spring & 9.18 \\
\hline 19 & A-19 & Bore Well & 6.30 & 51 & K-15. & Pond & 2.54 \\
\hline 20 & A-20 & Spring & 2.257 & 52 & K-16. & Spring & 1.78 \\
\hline 21 & A-21 & Spring & 6.30 & 53 & K-17. & Spring & 1.18 \\
\hline 22 & A-22 & Bore Well & 27.49 & 54 & K-18. & Spring & 1.11 \\
\hline 23 & A-23 & Bore Well & 2.05 & 55 & K-19. & Spring & 1.29 \\
\hline 24 & A-24 & Bore Well & 3.91 & 56 & K-20. & Spring & 9.57 \\
\hline 25 & A-25 & Spring & 2.86 & 57 & K-21. & Spring & 6.51 \\
\hline 26 & A-26 & Spring & 3.26 & 58 & K-22. & Spring & 15.71 \\
\hline 27 & A-27 & Stream & 4.87 & 59 & K-23. & Spring & 2.58 \\
\hline 28 & A-28 & Stream & 2.20 & 60 & K-24. & Spring & 5.00 \\
\hline 29 & A-29 & Spring & 3.15 & 61 & K-25. & Borewell & 10.40 \\
\hline 30 & A-30 & Spring & 1.04 & 62 & K-26. & Spring & 6.05 \\
\hline 31 & A-31 & Spring & 2.85 & 63 & K-27. & Spring & 22.17 \\
\hline 32 & A-32 & Stream & 1.22 & 64 & K-28. & Borewell & 17.11 \\
\hline
\end{tabular}




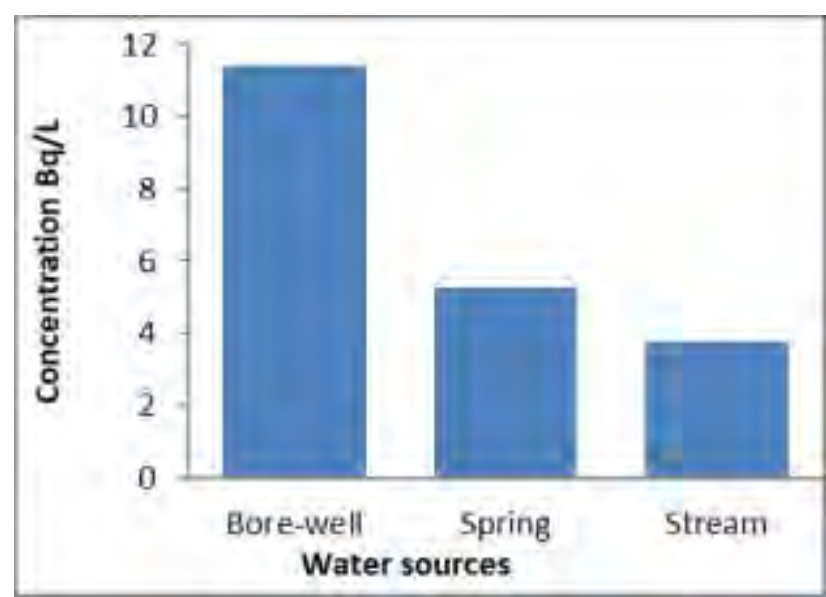

Figure 3: Comparison of average radon content in water from different sources in the study areas.

duces cancer development in smokers and non-smoker alike. It is estimated to be the second leading cause of lung cancer, specifically in the UK, after smoking. It is further established that lung cancer is enhances by radon among tobacco smoker (Robertson et al., 2013). As such Radon-222 and its decay products are listed in the International Agency for Research on Cancer (IARC) as Group 1 carcinogen, i.e. they are directly carcinogenic to humans (El Ghissassi et al., 2009). Therefore, it is important to assess the level or radon in our habitations and water sources, as radon is a naturally occurring gas.

The average radon content in water was found to be 7.33Bq/L in Aizawl District and 6.31Bq/L in Kolasib District. The total average content of radon in both districts was found to be $6.88 \mathrm{~Bq} / \mathrm{L}$ which was found to be within the safe limit of $11 \mathrm{~Bq} / \mathrm{L}$ prescribed by US EPA (EPA, 1998). But 7 samples from bore-well, i.e. A-6, A-9, A-10, A-14, A-22, K-1 and $\mathrm{K}-28$ and also 2 samples from springs, i.e. $A-2$ and $K-22$, the radon content were found to be higher than prescribed by the US EPA but are below the critical limit proposed by WHO (WHO, 2011).

\section{ACKNOWLEDGEMENT}

The authors would like to acknowledge the Board of Research in Nuclear Sciences, Department of Atomic Energy, Government of India, for providing financial assistance through the Research Project.

\section{REFERENCES}

El Ghissassi F, Baan R, Straif K, Grosse Y, Secretan B, Bouvard V, Benbrahim-Tallaa L, Guha N, Freeman C, Galichet L, Cogliano V (2009). A review of human carcinogens-part D: radiation. The Lancet Oncology. 10 (8), 751-752.

Environmental Protection Agency (1998). EPA's planned proposal of National Primary Drinking Water Regulation for Radon.

Ganesh, P, Yogesh, P, Gusain GS (2009). Variation of radon concentrations in soil and groundwater and its correlation with radon exhalation rate from soil in Budhakedar, Garhwal Himalaya. Indian J. Phys. 83 (6), 887-892

Manish, K, Anjali, K (2017). Measurement of uranium and radon concentration in drinking water samples and assessment of ingestion dose to local population in Jalandhar district of Punjab, India. Indoor and Built Environment 0(0), 1-8.

Nazaroff, WW, Nero, AV (1988). Radon and its decay product in indoor air. Environmental Science and Technology Volume 93. A Wiley-Interscience Publication.

Robertson A, Allen J, Laney R, Curnow A (2013). The cellular and molecular carcinogenic effects of radon exposure: a review. International Journal of Molecular Sciences. 14(7), 14024-14063.

Singh P, Singh P, Sahoo BK, Bajwa BS (2016). A study on uranium and radon levels in drinking water sources of a mineralized zone of Himachal Pradesh, India. Journal of Radioanalytical and Nuclear Chemistry. 309(2), 541-549.

United Nations Scientific Committee on the Effects of Atomic Radiation (1982). Exposure to Radon and Thoron and Their Decay Products. United Nations, New York.

United Nations Scientific Committee on the Effects of Atomic Radiation (2000). Sources and Effects of Ionizing Radiation. United Nations, New York.

WHO (2011). Guidelines for Drinking-Water Quality $\left(4^{\text {th }}\right.$ edition). World Health Organization Geneva, Switzerland: World Health Organization.

WHO (2011). Hand Book on Indoor Radon, A Public Health Perspective. Geneva, Switzerland: World Health Organization.

Yoon JY, Lee JD, Joo SW, Kang DR (2016). Indoor radon exposure and lung cancer: a review of ecological studies. Annals of Occupational and Environmental Medicine. 28(1), 15. 